\title{
ZÁBAVNÍ PRŮMYSL JAKO FAKTOR REGIONÁLNÍHO ROZVOJE: MÁ I ČESKÁ REPUBLIKA ODPOVÍDAJÍCÍ PŘEDPOKLADY?
}

\author{
Markéta Novotná, Josef Kunc, Petr Tonev, Jiř́ Husička
}

\begin{abstract}
This paper deals with the entertainment industry and its importance for tourism and regional development. It analyses the amusement parks and evaluates their economic aspects in Europe. The findings serve as a benchmark for comparing the situation in the Czech Republic. The size of demand, as well as current conditions, are taken into account. The analysis of relevant documents and data is employed. The case of the Czech Republic is based on the questionnaire survey. The analysis of European parks shows that the entertainment industry has some positive effects, such as the creation of new jobs, the promotion of tourism, and thus a direct impact on the economy. The situation in the Czech Republic is different; the entertainment industry is in the beginning. On the other hand, there is some potential for further development and expansion of parks, which can generate benefit to the local economy.
\end{abstract}

Keywords: amusement parks, tourism demand, economic impact, Czech Republic

\section{Úvod}

Zábavní průmysl prošel $\mathrm{v}$ minulosti zásadní přeměnou. Ačkoliv mají největší podíl na této dlouhodobé proměně Spojené státy americké, lze počátek zábavního průmyslu hledat v západní a severní Evropě. Pomineme-li středověké podoby zábavních trhů s atrakcemi v Dánsku či Anglii (Bakken, 2018), tak skutečné zábavní parky, jakožto součást zábavního průmyslu (Wroth, Wroth, 2016), začaly vznikat v Anglii ve druhé polovině 80. let 19. století (např. př́mořské letovisko Blackpool) a krátce poté se přesunuly na největší trh, tedy do USA.

V současné době mají zábavní parky zcela jinou podobu, a tudíž je možné sledovat, jak se zábavní průmysl v průběhu let změnil, jaký je jeho další rozvoj a jak vzhledem ke svému významu nejen pro ekonomický růst cestovního ruchu, ale i mnoha dalších odvětvích, přispívá k rozvoji regionu (Braun, 1999/2000). Proto je cílem př́spěvku zhodnocení základních socioekonomických aspektů vybraných evropských zábavních parků a jejich dopadů. Zjištění slouží pro porovnání situace v České republice a stanovení předpokladů pro budoucí expanzi a potenciální př́nos pro českou ekonomiku. Proto lze související výzkumnou otázku formulovat následovně: Má Česká republika předpoklady pro rozvoj zábavního průmyslu a dostatečný potenciál pro vznik nových zábavních parků? 


\section{Teoretická východiska a vývojové trendy}

Zábavním parkem se rozumí oblast, která slouží pro rekreaci. Jak vyplývá z názvu, zaměřuje se bud' na určité specifické téma, nebo je rozdělen na více tematických okruhů. Na základě tohoto tématu jsou v parku vybudovány atrakce (Braun, Soskin, 1999). Mezi tyto atrakce patří dle Collinse a Collinsové (2005) např. horské dráhy a kolotoče, vodní dráhy, vodní plochy, bobové dráhy, kina, divadla, obchody a stravovací zařízení.

Pro parky může být charakteristický určitý počet atrakcí umístěných na malém prostoru, kdy každá z těchto atrakcí má svou specifickou cenu (Clavé, 2007). Na druhou stranu existují parky tematické, které obsahují menší počet atrakcí velkého měřítka a jsou situované na rozsáhlém území. U tohoto typu parku se zisk nevytváří přímo prostřednictvím speciální ceny za vstup na atrakci, ale systém je pro návštěvníky nastaven tak, aby platili za celkový zážitek a prostředí pro rekreaci (Zukin, 1995).

Zábavní parky generují miliardy dolarů zisku, a proto mají podstatný vliv na místní ekonomiky. Jedním z hlavních prvků růstu ekonomiky tvoř́i export produktů a služeb do jiných regionů či států. V př́padě zábavních parků, jakožto jedné $\mathrm{z}$ atraktivit cestovního ruchu, má export podobu výdajů turistů za návštěvu. Tyto výdaje mají za následek multiplikační efekt, který dle Beavera (2005) spočívá v tom, že cestovní ruch prímo či nepríimo ovlivňuje řadu dalších odvětví. Další autoři, jako např. Lundberg (1995) vidí prrínos tohoto efektu v části těch výdajů, které zůstávají v ekonomice a umožňují její růst. Mezi další dopady zábavních parků se řadí zvýšení zaměstnanosti, daňových příjmů, růst ekonomiky a rozvoj regionu.

Také Gelná s Fialovou (2010) zdůrazňují, že s výstavbou parku dochází k posílení regionálního rozvoje a oživení cestovního ruchu $\mathrm{v}$ daném regionu. Př́kladem takového efektu spojeného $\mathrm{s}$ výstavbou zábavního parku v blízkosti města je nejenom vytvoření oblíbené destinace cestovního ruchu, ale také relokace doprovodných aktivit z centra města do okolí parku (Clavé, 2007). To, co z parku dělá skutečnou destinaci, která láká návštěvníky, je jeho charakter. Charakterem se rozumí zobrazení tématu, které působí na psychiku návštěvníků (Yegoiants, Samuelson, 2001). Z toho důvodu se může park stát tzv. vlajkovou atraktivitou, nebot' za působení multiplikačního efektu se stane hlavním motivem návštěvy regionu (Jolliffe, 2000, Nilsson et al., 2007).

Jak již bylo naznačeno, je tento průmysl, podobně jako další odvětví služeb, ovlivněn dostatečnou blízkostí velké kupní síly a ochotou návštěvníků za tyto služby platit (Csapó, Marton, 2017). Proto největší boom nastal v metropolitních oblastech Severní Ameriky. Podobný rozvoj se však podařil i v některých částech Evropy či Asie, nicméně vývoj na těchto kontinentech byl značně odlišný a charakteristický pomalým tempem růstu a vývojem pouze ve specifických oblastech (Clavé, 2007). 
Tab. 1: Tempo růstu zábavních parků ve světě.

Table 1: The growth of amusement parks in the world

\begin{tabular}{|l|l|l|l|l|}
\hline Etapa & USA - Kanada & Evropa & Asie - Pacifik & $\begin{array}{c}\text { Zbytek } \\
\text { světa }\end{array}$ \\
\hline 1950 & Start & & & \\
\hline 1960 & Rozvoj & Start & & \\
\hline 1970 & Expanze & Rozvoj & Start & \\
\hline 1980 & Zrání & Expanze & Rozvoj & Start \\
\hline 1990 & Koncentrace & Adaptování & Expanze & Rozvoj \\
\hline 2000 & Diverzifikace & Repositioning & Selektivní růst & Expanze \\
\hline
\end{tabular}

Zdroj: Clavé (2007)

Z tab. 1 je patrné, že v USA a Kanadě již dosáhnul zábavní průmysl vrcholu a nyní přechází do fáze specializace a vytváření nových strategií, kdežto vývoj v Evropě je teprve ve fázi repositioningu. Tato fáze souvisí se změnou image vzhledem $\mathrm{k}$ ostatním konkurentům a cílovému trhu. Jelikož je toto období spojováno se změnou marketingové strategie vycházející z poznání nových trendů a problémů, je také nutně spojeno se značnými finančními náklady. Jones a Robinett (1998) proto tuto fázi popisují jako období investic a marketingu. Přední evropské parky proto začínají investovat do rozšíření a zkvalitnění své nabídky, a to především prostřednictvím inovace atrakcí, rozvíjení doprovodných služeb a aktivního př́istupu $\mathrm{k}$ návštěvníkům. Investice do rozvoje tak tvoří náklady parků (Formica a Olsen, 1998). Zábavní parky jsou charakteristické vysokými fixními náklady a malými variabilními náklady, tj. mezní náklady na dalšího návštěvníka mají zanedbatelný vliv na celkové náklady (Avlonitis a Indounas, 2005 a Tribe, 2011). Za účelem maximalizace zisku by se z ekonomického pohledu měla cena za vstup odvíjet právě od mezních nákladů (Oi, 1971), což je nutné vzít v úvahu i při nastavení cenové strategie (Nahata et al., 1999, Sundararajan, 2004).

Po velmi úspěšných meziválečných letech se však do roku 1950 většina zábavních parků dostala do havarijního stavu, trpěla špatným obrazem veřejnosti a v důsledku velké hospodářské krize a následné 2 . světové války měla finanční potíže. Až v polovině 50 . let se podařilo Waltu Disneymu revitalizovat průmysl zábavních parků, když otevřel svůj koncepčně převratný Disneyland v Anaheimu v Kalifornii (1955) v multitematickém konceptu s využitím pro všechny věkové kategorie (Sun, Uysal, 1994). Mnoho amerických a později i evropských parků se snažilo tento koncept převzít, ale žádný z nich se nedočkal takové slávy (Testa, Sehlinger, 2016).

Úspěch zábavních parků byl zapř́íčiněn také vzestupem vlastnictví automobilů, které zvýšily mobilitu a umožnily lidem navštěvovat ve svých zemích 
více izolovaných a dřive nepřístupných parků. I rostoucí bohatství nižší a střední třídy přispělo k nové možnosti využívání jejich volného času. Také delší víkendy a placené dovolené pomohly podpořit expanzi návštěv zábavních parků (Clavé, Clark, 2007). Od konce 20. století se díky globalizaci začala výstavba parků šírit po celém světě.

\section{Data a metody šetření}

Za účelem zhodnocení ekonomických aspektů vybraných evropských zábavních parků a jejich socioekonomických dopadů byla provedena analýza dokumentů a sekundárních zdrojů. Pro vyčíslení ekonomických dopadů zábavního průmyslu $\mathrm{v}$ Evropě byly využity zejména dokumenty mezinárodní asociace zábavního průmyslu IAAPA (2017) a výroční zprávy vybraných evropských zábavních parků. Při výběru evropských př́kladů byly zohledněny ty země, které mají větší počet členů IAAPA (viz mapa 1), zároveň jsou i populačně srovnatelné a mají tudíž i srovnatelný vnitřní trh zábavního průmyslu. Následující graf představuje přehled vybraných zemí Evropy s významným zastoupením členů IAAPA, včetně České republiky a Slovenska pro možnou komparaci, a to $\mathrm{v}$ přepočtu na 1 mil. obyvatel.

Graf 1: Počet členů mezinárodní asociace IAAPA (na 1 mil. obyvatel)

Graph 1: Number of IAAPA members (per 1 million inhabitants)

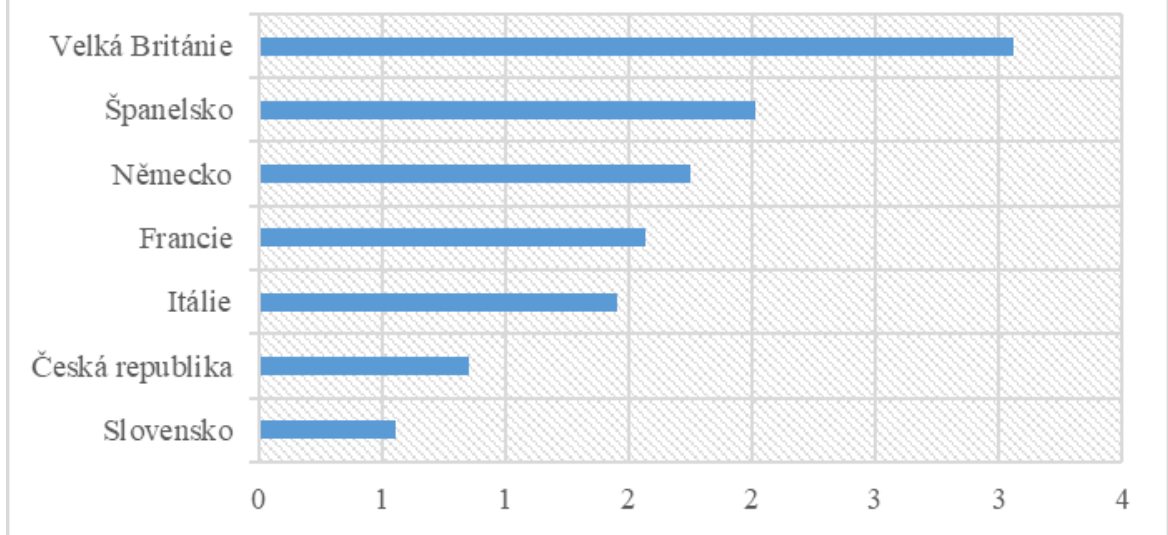

Zdroj: IAAPA (2017), vlastní výpočty

Na základě analýzy a syntézy relevantních dat došlo následně k vyvození závěrů o socioekonomickém významu zábavních parků. Pro posouzení situace $\mathrm{v}$ České republice a vyhodnocení eventuálních přínosů pro českou ekonomiku bylo nutné realizovat dotazníkové šetření, které přispělo ke zjištění velikosti poptávky a 
odhadu ekonomických dopadů, resp. významu zábavního průmyslu pro regionální rozvoj.

Respondenti byli cíleně vybíráni na základě kvótního výběru tak, aby výsledný vzorek odpovídal věkové struktuře České republiky (ČSÚ, 2017) a tvořil obraz této struktury s ohledem na věkovou strukturu návštěvníků zábavních parků světa. Dotazník byl rozeslán elektronickou formou mezi 300 respondentů, přičemž v první vlně předvýzkumu byl menší počet dotazníků (20) distribuován v univerzitním prostředí mezi populaci ve věku 25-45 let, která tvoří rozhodující podíl při návštěvách vybraných atraktivit. Následně byla využita metoda sněhové koule (snowball sampling), kdy první respondenti z realizovaného předvýzkumu rozeslali cílový objem dotazníků známým, př́buzným apod. Tato metoda je v obdobných výzkumech zcela běžně využívána.

Takto bylo získáno 138 dotazníků. Návratnost tedy činila 46 \%. Dle Průchy a kol. (1995) bývá návratnost elektronických dotazníků okolo $30 \%$, tudíž se toto šetření dá považovat za ilustrativní s určitou vypovídací schopností, ale nikoliv zcela reprezentativní pro zobecnění výsledků na národní úrovni. Výsledky šetření byly následně zpracovány, vyhodnoceny a graficky znázorněny. Pro účely našeho př́spěvku prezentujeme pouze vybrané relevantní výsledky.

\section{Zhodnocení zábavního průmyslu v Evropě}

Zábavní průmysl aktuálně v Evropě zahrnuje více než 310 zábavních a tematických parků, které provozují kolem 50 hotelů. V roce 2012 (novější data zatím IAAPA nezveřejnila) zábavní parky vyprodukovaly 4,9 miliard EUR, z čehož $80 \%$ tvořily ceny vstupenek, $16 \%$ prríjmy ubytovacích zařízení a $4 \%$ sponzorské a firemní akce. Parky zaměstnávaly přes 53100 zaměstnanců, kteří vytvořili náklady na mzdy ve výši 1,5 miliard EUR za rok. Následující mapa ilustruje prostorové rozmístění členů mezinárodní asociace IAAPA působících na trhu zábavního průmyslu v Evropě, resp. v zemích EU, Islandu, Norska a Švýcarska.

Dle průzkumu provedeného mezinárodní asociací zábavního průmyslu bylo zábavním průmyslem $\mathrm{v}$ roce 2012 vytvořeno celkem 9,3 miliard EUR zisku, přilákáno více než 460 milionu návštěvníků a zaměstnáno 115 tisíc lidí. Detailnější informace o dopadech evropského zábavního průmyslu zobrazuje tab. 2, kde jsou dopady rozděleny na přímé a neprímé podle již dříve zmíněného multiplikačního efektu.

V porovnání s USA je však evropský trh na základě příjmů stále pouze třetinový (IAAPA, 2017). Důvodem menšího rozmachu zábavního průmyslu v Evropě je dle Campa (1997) nižší poptávka po těchto službách. Mezi další důvody patří nižší míra investic a výdajů na marketing. I přesto lze říci, že poptávka po nových zábavních parcích v Evropě stále roste a stejně tak dochází i ke zvětšování kapacit již zavedených parků. 
Mapa 1: Rozmístění členů IAAPA v Evropě

Map 1: Distribution of IAAPA Members in Europe

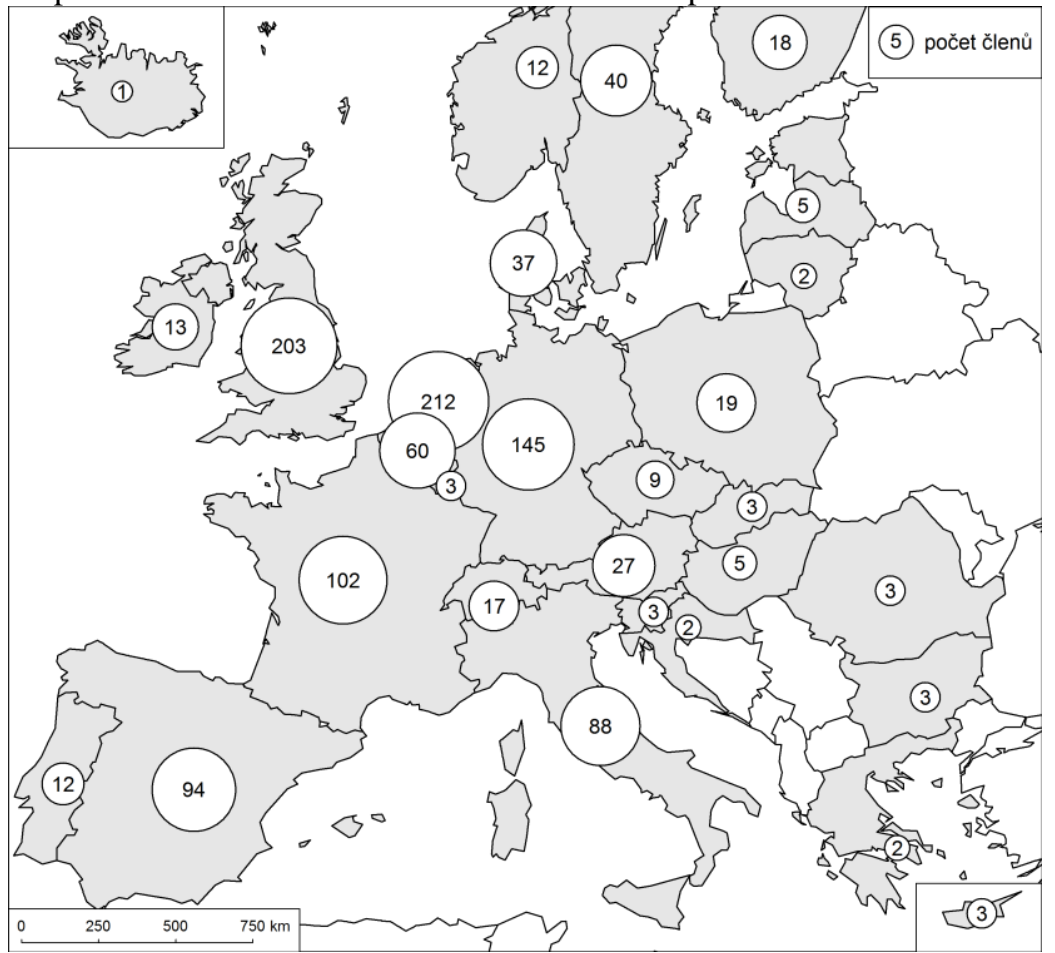

Zdroj: IAAPA (2017)

Tab. 2: Dopady evropského zábavního průmyslu v roce 2012

Table 2: The impacts of the European entertainment industry in 2012

\begin{tabular}{|c|c|c|c|c|c|c|}
\hline & \multicolumn{4}{|c|}{ Přímé dopady } & \multicolumn{2}{|c|}{ Nepřímé dopady } \\
\hline & $\begin{array}{c}\text { Počet } \\
\text { atraktivit }\end{array}$ & $\begin{array}{c}\text { Návštěvnost } \\
\text { (v mil.) }\end{array}$ & $\begin{array}{c}\text { Př́ijmy } \\
\text { (mld. } \\
\text { EUR) }\end{array}$ & $\begin{array}{c}\text { Počet } \\
\text { pracovních } \\
\text { pozic (tis.) }\end{array}$ & $\begin{array}{c}\text { Hodnota } \\
\text { (mld. } \\
\text { EUR) }\end{array}$ & $\begin{array}{c}\text { Počet } \\
\text { pracovních } \\
\text { pozic (tis.) }\end{array}$ \\
\hline $\begin{array}{l}\text { Zábavní } \\
\text { parky }\end{array}$ & 307 & 149,5 & 4,9 & 53,1 & 10,0 & 109,0 \\
\hline Aquaparky & 188 & 76,4 & 0,9 & 17,3 & 1,8 & 35,8 \\
\hline $\begin{array}{l}\text { Rodinná } \\
\text { centra }\end{array}$ & 1116 & 49,1 & 0,3 & 5,9 & 0,6 & 12,3 \\
\hline $\begin{array}{l}\text { Vědecká } \\
\text { centra }\end{array}$ & 187 & 42,7 & 1,0 & 10,8 & 2,0 & 22,5 \\
\hline $\begin{array}{l}\text { Zoologické } \\
\text { zahrady }\end{array}$ & 321 & 142,5 & 2,3 & 28,4 & 4,8 & 58,9 \\
\hline Celkem & 2119 & 460,3 & 9,4 & 115,5 & 19,3 & 238,4 \\
\hline
\end{tabular}

Zdroj: IAAPA (2017) 
Nejdůležitějším hráčem na evropské scéně je Francie, která svými příjmy dosahuje $34 \%$ celkových prŕímů zábavního průmyslu Evropy. Následuje Velká Británie a Německo (16 \% a $12 \%)$. Lze proto říci, že velké množství evropských parků se soustřed'uje v severní a severozápadní Evropě, kde je největší kupní síla z celé Evropy. Ve Francii se nachází 44 zábavních a tematických parků, které v roce 2012 přilákaly 29,1 milionů návštěvníků. Největším a nejnavštěvovanějším z těchto parků, který byl otevřen roku 1992, je Disneyland Paris. První roky existence však ukázaly, že Disneyland Paris, který podle ekonomických prognóz potřeboval návštěvnost minimálně 14 miliónů, přičemž jeho kapacita byla 12 miliónů, nebyl zdaleka tak úspěšný, nebot' skutečná poptávka činila pouhých 9 miliónů (Clavé, 2007). K jeho uzavření tehdy nedošlo pouze díky investicím francouzské vlády.

Také zábavní průmysl Velké Británie je se svými 58 parky relativně velký. Druhým největším evropským tematickým parkem jak rozlohou, tak návštěvností, je právě britský Blackpool Pleasure Beach. Tento tematický park, který lze zařadit mezi nejstarší na světě, začínal jako přímořské letovisko pro bohaté. Prvotním impulsem pro jeho vznik bylo zavedení železnice a rozvoj města. Od druhé poloviny 19. století začal Blackpool prosperovat a velmi rychle růst.

V Německu se nachází 77 tematických a zábavních parků. Nejvýznamnějším německým tematickým parkem, který byl otevřen roku 1975 ve spolkové republice Bádensko-Württembersko, je Europa-Park. Od doby svého otevření se park zařadil mezi celosvětově významné. Se svými téměř pěti miliony návštěvníků za rok náleží mezi pět nejvýznamnějších parků v Evropě. Návštěvnost parků ve výše zmíněných evropských městech, stejně jako zisk a počty zaměstnaných shrnuje tab. 3 .

Tab. 3: Význam zábavního průmyslu ve vybraných zemích Table 3: Importance of the entertainment industry in selected countries

\begin{tabular}{|l|r|r|r|}
\hline & \multicolumn{1}{|c|}{ Francie } & Velká Británie & \multicolumn{1}{c|}{ Německo } \\
\hline $\begin{array}{l}\text { Roční počet } \\
\text { návštěvníků }\end{array}$ & 29,1 mil. & 24,2 mil. & 27,2 mil. \\
\hline Př́ijmy & 1,7 mld. EUR & 0,58 mld. EUR & 0,78 mld. EUR \\
\hline Kapitálové výdaje & 197 mil. EUR & 69 mil. EUR & 94 mil. EUR \\
\hline Počet zaměstnanců & 17,1 tis. & 7,3 tis. & 9,7 tis. \\
\hline Mzdy zaměstnanců & 644 mil. EUR & 169 mil. EUR & 220 mil. EUR \\
\hline Příspěvek ekonomice & 1,4 mld. EUR & 0,48 mld. EUR & 0,55 mld. EUR \\
\hline
\end{tabular}

Zdroj: IAAPA (2017), vlastní úpravy 


\section{Potenciál rozvoje zábavního průmyslu v České republice}

Česká republika se v zábavním průmyslu velmi liší od západní Evropy a zbytku světa. Velikost parků, ani jejich zázemí a vybavení nedosahují zdaleka takové úrovně, jako napríklad v sousedním Německu. Co se týče počtu parků, situace je velmi podobná. Česká republika je charakteristická množstvím aquaparků a sérií malých zábavních parků, z nichž jsou nejznámější tzv. dinoparky Rozmístění těchto vybraných atraktivit znázorňuje níže uvedená mapa 2.

Mapa 2: Rozmístění vybraných atraktivit zábavního průmyslu v České republice Map 2: Distribution of entertainment industry attractions in the Czech Republic

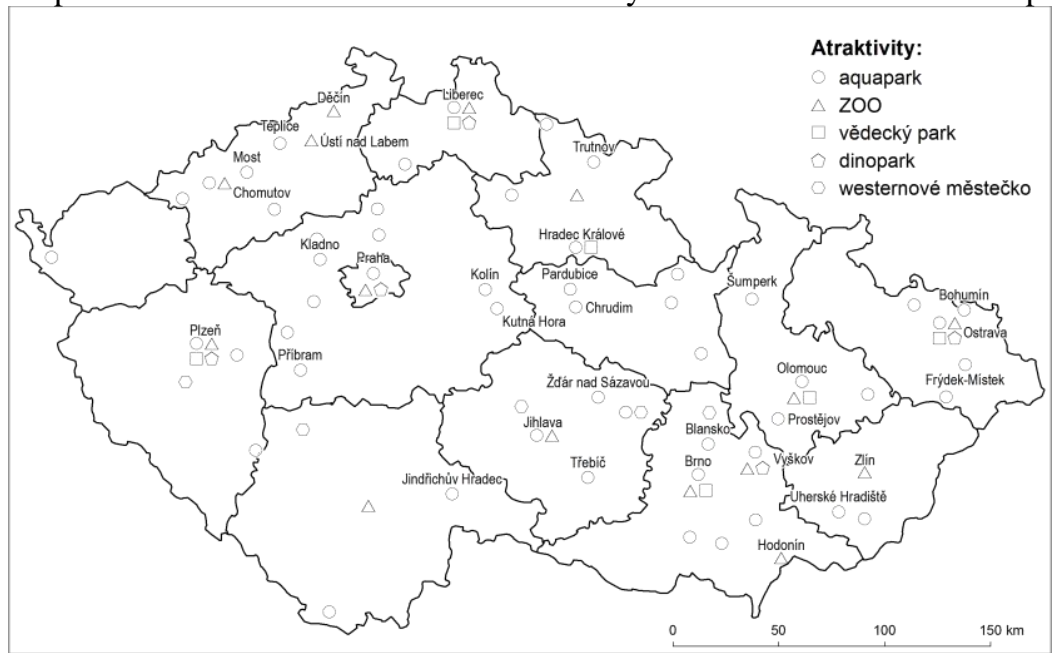

Zdroj: vlastní zpracování

Prvním krokem vedoucím $\mathrm{k}$ vytvoření závěrů týkajících se zjištění potenciálních prŕnosů pro českou ekonomiku a silných a slabých stránek dalšího rozvoje je analýza vnitřního a vnějšího prostředí. Je potřeba identifikovat a vyhodnotit místní trh a odhadnout turistický potenciál. Za tímto účelem bylo realizováno šetření týkající se povědomí o zábavním průmyslu.

$Z$ celkového počtu respondentů jich více než $4 / 5$ navštívilo nějaký zábavní park. Celkem 98 dotazovaných navštívilo některý z evropských parků. Ovšem i ostatní respondenti, kteří navštívili pouze český zábavní park nebo žádný, měli ze $75 \%$ o evropských parcích povědomí. Evropské parky pak podle českých klientů dosahují oproti českým atraktivitám velké kvality. Více než $2 / 3$ českých klientů bylo při návštěvě některého $\mathrm{z}$ evropských parků velmi spokojeno, zatímco s atrakcemi malých českých zábavních parků bylo spokojena zhruba pouze 1/5. Na druhou stranu je 36,2 \% dotázaných zcela s kvalitou a úrovní nespokojeno. 
Kvalita parků odráží do určité míry také ochotu návštěvníků platit. Evropský průměr cen vstupů, které se pohybují do 35 EUR (IAAPA, 2017), by bylo ochotno zaplatit 61 respondentů $(44,4 \%)$. Více než $3 / 4$ oslovených by také rádo využívalo doplňkové služby, které zábavní parky nabízejí. Z výzkumu vyplynulo, že největší zájem byl o stravování (79,2 \%), následované doprovodnými atrakcemi, které zvolilo 37,5 \% respondentů. Poslední dvě doplňkové služby, které parky nabízejí, jsou nákupy a ubytování (zhruba čtvrtina respondentů).

Významným zjištěním, které přispěje k odhadu potenciálních přínosů, je i doba strávená návštěvou atraktivit. Přes $70 \%$ respondentů parky navštěvuje pravidelně. Ve většině př́ípadů jsou navštěvovány po dobu celého dne $(47,2 \%)$ nebo po dobu několika hodin (45,8 \%). Pouhých 5,6 \% respondentů v parku stráví méně než hodinu. Až na výjimky se žádný z respondentů se do parku již druhý den nevrací.

Jedna $\mathrm{z}$ posledních otázek směřovala také $\mathrm{k}$ podpoře výstavby zábavního parku evropského formátu. Dle počtu odpovědí byly dvě třetiny dotázaných pro výstavbu a následnou návštěvu tematického parku na území ČR. Je možné se tedy domnívat, že v České republice skutečně existuje potenciál pro vznik tematického parku evropského formátu.

\section{Závěr}

S ohledem na př́jmy, které zábavní průmysl generuje, může tento přispět $\mathrm{k}$ ekonomickému rozvoji regionu. Výstavbou parku lze docílit oživení cestovního ruchu $\mathrm{v}$ daném regionu i relokace doprovodných aktivit do okolí parku. Návštěvnost a ekonomickou úspěšnost parků zvyšuje také jejich přirozená koncentrace $\mathrm{v}$ urbánním prostředí (většinou, ale nikoliv nutně), kde se nacházejí další turistické památky a atraktivity (Butowski, 2018). Vytváŕí se tak multiplikační efekt výhodný pro podnikatele i region. Postsocialistická Evropa však v těchto atributech zatím za vyspělým ,západním“ světem výrazně zaostává (Gelná, Fialová, 2010, Šenková et al., 2015, Kasagranda, 2015, Ot’ahel’ et al., 2018, Novaská a kol., 2018).

Z výsledků šetření vyplývá, že v České republice existuje poptávka po tomto druhu rekreace a zábavy. Slabým místem pro rozvoj zábavního průmyslu je však velký podíl jednodenních návštěvníků, kteří představují až o $80 \%$ méně př́ijmů, než je tomu v prŕípadě vícedenních pobytů (Jones a Robinett, 1998). Jednodenní návštěvníci navíc zatěžují infrastrukturu a životní prostř̌edí. Při hodnocení návštěvnosti pouze podle počtu návštěvníků může dojít také $\mathrm{k}$ nadhodnocení prrínosu parku (Dziomba, Beyerle, 2003). Tento problém byl patrný i v kontextu západní Evropy, kdy v několika př́ípadech byly parky před uzavřením uchráněny investováním veřejných prostředků. Problematické je i nedostatečné množství movité tuzemské klientely. Na druhou stranu výhodná poloha České 
republiky je zároveň předpokladem dosažitelné vzdálenosti sousedních států, které by tvořily velkou část klientely. Tato prognóza je založená na zkušenosti se zahraničním cestováním sousedních států, převážně pak Němců a Rakušanů (Horner, Swarbrooke, 2003).

Další silnou stránkou, kterou disponuje český trh, jsou relativně rozlehlé opuštěné a nevyužívané lokality, které mohou být vhodné pro budoucí výstavbu zábavních parků, např. v rámci projektů regenerace brownfields, jak je tomu již řadu let v zahraničí (např. Edwards, Llurde's, 1996, Franz et al., 2008). Tyto lokality se navíc nacházejí ve městech a často v atraktivní poloze, což na Západě není tak obvyklé.

Pro vyhodnocení možnosti rozvoje zábavního průmyslu a jeho př́nosů je kromě velikosti a kvality poptávkové strany nezbytným krokem i další analýza nákladů a prrínosů, porovnání společenských nákladů a př́nosů a následné vyhodnocení přijatelnosti dalších projektů v této oblasti, což je otázkou dalšího možného výzkumu.

\section{Poděkování}

Př́spěvek byl zpracován v rámci projektu Města, obce, regiony: management, procesy a interakce v teorii a praxi; MUNI/A/0994/2017.

\section{Literatúra}

AVLONITIS, G. J. - INDOUNAS K. A. 2005. Pricing objectives and pricing methods in the services sector. In Journal of Services Marketing. vol. 19, no. 1, pp. 47-57.

BAKKEN. 2018. The worlds oldest amusement park. [online]. 2018. [cit. 2018-0905]. Dostupné na internete: 〈https://www.bakken.dk/english/>.

BEAVER, A. 2005. A dictionary of travel and tourism terminology. New York: CABI Pub., 2002. 380 p. ISBN 08-519-9582-9.

BRAUN, M. 1999/2000. The economic impact of theme parks on regions. In NEURUS - participant 1999/2000 (UCI - WU) [online]. 1999/2000. [cit. 201809-05]. Dostupné na internete: 〈http://www-sre.wu.ac.at/neurus/braun.pdf >.

BRAUN, M. - SOSKIN, M. D. 1999. Theme Park Competitive Strategies. In Annals of Tourism Research. ISSN 0160-7383, 1999, vol. 26, no. 2.

BUTOWSKI, L. 2018. An integrated AHP and PROMETHEE approach to the evaluation of the attractiveness of European maritime areas for sailing tourism. In Moravian Geographical Reports. ISSN 1210-8812, 2018, vol. 26, no. 2, pp. 135-148.

CAMP, D. 1997. Theme Parks in Europe. In Travel \& Tourism Analyst. vol. 5, pp. 42-47. 
CLAVÉ, S. A. - CLARK, A. 2007. The Global Theme Park Industry. Oxford: Oxford University Press, 2007. 480 p. ISBN 978-1845932084.

CLAVÉ, S. A. 2007. The global theme park industry. Cambridge, MA : CABI, 2007. 459 s. ISBN 978-184-5932-084.

COLLINS, L. K. - COLLINS, L. 2005. 31 Months in Japan: The Buildin of a Theme Park. iUniverse, Inc, 2005. 234 p. ISBN 978-0595345847.

CSAPÓ, J. - MARTON, G. 2017. The Role and Importance of Spa and Wellness Tourism in Hungary's Tourism Industry. In Czech Journal of Tourism. ISSN 1805-3580, 2017, vol. 6, no. 1, pp. 55-68.

ČSÚ. 2017. Věková struktura [online]. 2017. [cit. 2018-09-23]. Dostupné na internete: 〈https://www.czso.cz/staticke/animgraf/cz/index.html?lang=cz>.

DZIOMBA, M. - BEYERLE, T. 2003. Freizeitimmobilien: ein Marktsegment gewinnt an Gewicht und Professionalität. Standort. In Zeitschrift für angewandte Geographie. vol. 27, no 3, pp. 1-12.

EDWARDS, J. A. - LLURDE'S, J. C. 1996. Mines and quarries: Industrial heritage tourism. In Annals of Tourism Research. ISSN 0160-7383, 1996, vol. 23, no. 2, pp. 341-363.

FORMICA, S. - OLSEN, M. D. 1998. Trends in the amusement park industry. In International Journal of Contemporary Hospitality Management. vol. 10, no. 7, pp. 297-308

FRANZ, M. - GÜLES, O. - PREY, G. 2008. Place-making and 'Green' Reuses of Brownfields in the Ruhr. In Tijdschrift voor Economische en Sociale Geografie. ISSN 1467-9663, 2008, vol. 99, pp. 316-328.

GELNÁ, T. - FIALOVÁ, D. 2010. Ekonomické dopady zábavních komplexů na regiony. In Regionální Studia. ISSN 1803-1471, 2010, roč. 4, č. 1, s. 17-23.

HORNER, S. - SWARBROOKE, J. 2003. Cestovni ruch, ubytování a stravování, využití volného času. Grada Publishing, 2003. 488 s. ISBN 80-247-0202-9.

IAAPA. 2017. European Amusement Parks and Attractions. Driving Leisure and Tourism [online]. 2017. [cit. 2018-09-17]. Dostupné na internete: $<$ http://www.iaapa.org/docs/default-source/EAS-2017-exhibit/iaapa_manifesto _2017_final.pdf?sfvrsn=2>.

JOLLIFFE, L. 2000. Theme Parks as Flagship Attractions in Peripheral Areas. In Annals of Tourism Research. vol. 27, no. 1, pp. 250-252.

JONES, C. B. - ROBINETT, J. 1998. The future of theme parks in international tourism. In Economic Research Associates. 1998.

KASAGRANDA, A. 2015. Spatial differentiation and evaluation of tourism performance of Slovakia and its specificities. In Czech Journal of Tourism. ISSN 1805-3580, 2015, vol. 4, no. 1, pp. 58-74.

LUNDBERG, C. 1995. Learning in and by organizations: Three conceptual issues. In The International Journal of Organizational Analysis. vol. 3, no. 1, pp. 1023. 
NAHATA, B. et al. 1999. Buffet Pricing. In The Journal of Business. vol. 72, no. 2, pp. 32-42.

NILSSON, P. A. et al. 2007. Stakeholder Theory: The Need for a Convenor. The Case of Billund. In Scandinavian Journal of Hospitality and Tourism. vol. 7, no. 2, pp. 227-261

NOVANSKÁ V. - BENOVÁ, A. - GEGHAMYAN, S. 2018. Možnosti rekreácie $\mathrm{v}$ meste Bratislava na základe percepcie miestneho obyvatelstva. In Geographia Cassoviensis. ISSN 1337-6748, 2018, roč. 12, č. 1, s. 110-128.

OI, W. Y. A Disneyland Dilemma: Two-Part Tariffs for a Mickey Mouse Monopoly. The Quarterly Journal of Economics. vol. 85, no. 1.

OŤAHEL', J. - IRA, V. - HLAVATÁ, Z. - PAZÚR, R. 2018. Visibility and perception analysis of city monuments: The case of Bratislava city centre (Slovakia). In Moravian Geographical Reports. ISSN 1210-8812, 2018, vol. 26, no. 1, pp. 55-68.

PRŮCHA, J. - WALTEROVÁ, E. - MAREŠ, J. 1995. Pedagogický slovník. 1. vyd. Praha: Portál, 1995. 292 s. ISBN 80-717-8029-4.

SUN, L. H. - UYSAL, M. 1994. The Role of Theme Parks in Tourism. In Hospitality Review. vol. 12, no. 1.

SUNDARARAJAN, A. 2004. Nonlinear Pricing of Information Goods. In Management Science. vol. 50, no. 12, pp. 1660-1673.

ŠENKOVÁ, A. - MITRÍKOVÁ, J. - ANTOLÍKOVÁ, S. 2015. Analysis of the selected trends in tourism and hotel industry in Slovak Republic in 1989-2000. In Economic Annals. ISSN 1728-6220, 2015, vol. 1-2, no. 1, pp. 62-65.

TESTA, B. - SEHLINGER, L. 2016. The unofficial guide to Walt Disney World. Unofficial Guides. Birmingham: Keen Communications, 2016. 864 p.

TRIBE, J. 2011. The economics of recreation, leisure and tourism. London: Routledge, 2011. 508 p. ISBN 9781136434556.

WROTH, W. W. - WROTH, E. A. 2016. The London pleasure gardens of the eighteenth century. New York: Macmillan, 2016. 372 p.

YEGOIANTS, W. - SAMUELSON, D. 2001. The American amusement park. St. Paul, MN: MBI Publishing, 2001. 322 p. ISBN 978-076-0309-810.

ZUKIN, S. 1995. The cultures of cities. Cambridge, MA: Blackwell, 1995. 322 p.

\section{ENTERTAINMENT INDUSTRY AS A FACTOR OF REGIONAL DEVELOPMENT: DOES THE CZECH REPUBLIC HAVE THE APPROPRIATE ASSUMPTIONS?}

\section{Summary}

According to its influence on the various economic sectors and the revenues it generates, the entertainment industry can contribute to the development of a region. The expansion of the amusement parks can cause a revival of tourism in the 
region and the relocation of accompanying activities to the surrounding area. Among the increase in tax revenues, other positive effects of the entertainment industry include also raising employment.

This industry, like other services sectors, is affected by the proximity of purchase power and the willingness of visitors to pay for these services. Therefore, the biggest boom of this industry occurred in metropolitan areas of North America. However, a similar development was achieved in some parts of Europe. Compared to North America, the European market is still only at the third performance in terms of revenues. The most important player in this industry in Europe is France, which earns $34 \%$ of the European entertainment industry's revenue, followed by Great Britain and Germany (16 and 12\%).

On the other hand, post-socialist Europe lags far behind the developed "Western" world. This is the reason why the Czech Republic differs in the performance of the entertainment industry and its expansion from Western Europe and the rest of the world. The size of the amusement parks, their background, and equipment is far from the standard of German parks. The first step leading up to the conclusions regarding the identification of potential benefits for the Czech economy and the strengths and weaknesses of further development was the analysis of the internal and external environment. It was necessary to identify and evaluate the local market and to estimate the potential of the entertainment industry. For this purpose, a survey of entertainment awareness was carried out. The results of the survey show that there is a demand for this type of recreation and entertainment in the Czech Republic.

However, the weak side of this demand for the further development of the entertainment industry is a large share of one-day visitors, who contribute up to $80 \%$ fewer revenues than multi-day visitors. These visitors can also burden infrastructure and the environment. When evaluating only the number of visitors, the benefits of the parks may also be overestimated. This problem was also evident in Western Europe, where the parks had to be sometimes supported by public funds to prevent their closure. Problems can be caused by the insufficient number of Czech wealthy clients. On the other hand, the advantageous position of the Czech Republic is also a prerequisite for the reachable distance of neighbouring states, which could form a large part of the potential clientele. Another strong point for the expansion of the entertainment industry in the Czech Republic is a number of brownfields that may be suitable for the future construction of amusement parks.

\section{Ing. Markéta Novotná, Ph.D.}

Katedra regionální ekonomie a správy, Institut cestovního ruchu

Ekonomicko-správní fakulta

Masarykova univerzita

Lipová 41a, 60200 Brno-Pisárky

E-mail: marketa.bobkova@econ.muni.cz 


\section{Doc. RNDr. Josef Kunc, Ph.D.}

Katedra regionální ekonomie a správy

Ekonomicko-správní fakulta

Masarykova univerzita

Lipová 41a, 60200 Brno-Pisárky

E-mail: josef.kunc@econ.muni.cz

Mgr. Petr Tonev, Ph.D.

Katedra regionální ekonomie a správy

Ekonomicko-správní fakulta

Masarykova univerzita

Lipová 41a, 60200 Brno-Pisárky

E-mail: petr.tonev@econ.muni.cz

Ing. Jiř́i Husička

Katedra regionální ekonomie a správy

Ekonomicko-správní fakulta

Masarykova univerzita

Lipová 41a, 60200 Brno-Pisárky

E-mail: 405766@mail.muni.cz 